\title{
Hóspedes E PeREgRINOS: SOBRE A CONSTRUÇÃO DE CAMINHOS POSSÍVEIS NA PSICOSE
}

\author{
Adriana Cerdeira da Silva Gutman
}

Esta dissertação se propõe a pesquisar caminhos na psicose que não sejam, exclusivamente, os caminhos que se utilizam da metáfora paterna nem tampouco da metáfora delirante. Trabalharemos com a idéia de que em ambas as operações há um elemento estabilizador da cadeia que se utiliza ou da unidade simbólica ou da unidade imaginária. Tendo abordado as estradas paternas, investigaremos os caminhos de chão, que seriam os caminhos alternativos para se obter algum sentido de estabilização. Para abordarmos esse tema faremos um breve percurso pela obra de Jacques Lacan dos anos 50 aos anos 70, quando ele propõe, através da teoria sobre o nó borromeano, que o Nome-do-Pai seria um dentre outros significantes capazes de assumir o lugar central do significante unificador. $\mathrm{O}$ pano de fundo dessa discussão será o trabalho realizado no Hospital Psiquiátrico de Jurujuba com pacientes moradores do Albergue. Finalmente, para abordar esses percursos possíveis na psicose nos utilizaremos de dois termos que nos pareceram rentáveis para a discussão, são eles: Hóspedes e Peregrinos.

\section{BANCA:}

Marcus André Vieira (Orientador)

Ana Cristina Costa de Figueiredo

Angélica Bastos de Freitas Rachid Grimberg

Data da defesa: 18/03/2009 